\title{
Applicability of DDBD approach on low-rise RC buildings situated in Indian seismic regions
}

\author{
Anurag Sharma ${ }^{1} \cdot$ R. K. Tripathi ${ }^{1} \cdot$ Govardhan Bhat $^{1}$
}

Received: 26 June 2021 / Accepted: 19 August 2021 /Published online: 15 September 2021

(c) The Author(s), under exclusive licence to Springer Nature Switzerland AG 2021

\begin{abstract}
Design of reinforced concrete (RC) buildings with a direct-displacement-based design (DDBD) method has been used extensively for the last few decades around the world. As compared to force-based design (FBD) method, DDBD provides advantages in cost-reduction, construction timing, and better structural performance. This paper investigates the DDBD methodology for $\mathrm{G}+3$ storied RC buildings, having different structural configurations by varying bays in the longitudinal and transverse directions, but having the same total plan area. The selected case-study RC buildings are analysed via non-linear time history analysis considering seismicity of zone-V of Indian regions. A suite of different spectrum compatible ground motions is used. The seismic behaviour has been analysed in terms of base-shear ratio, ductility demand, displacement profiles and drift ratios. The results illustrate that the DDBD procedure proves to be useful in designing RC buildings situated in seismic regions of India and are competent enough to withstand lateral forces due to seismic excitations.
\end{abstract}

Keywords Displacement-based design $\cdot$ RC buildings $\cdot$ Nonlinear analysis $\cdot$ Base shear $\cdot$ Drift ratios

\section{Introduction}

Contemporary design practices of structures consider forcebased design (FBD) method for designing of structures. Current national codes, i.e. IS 1893 (2016) [1] of India, Standard No. 2800 (2014) [2] of Iran, Eurocode (EC8) (2004) [3] of Europe, ASCE 7-16 (2016) [4] of USA and NBCC (2015) [5] of Canada follows FBD method for seismic design. In FBD, buildings are primarily designed for an elastic response for forces under design-basic earthquake (DBE) as given in national codes. From the literatures, it has been found that even though FBD sound conceptually good for elastic behaviour, but under severe earthquakes, it fails to distribute forces and loads across the buildings in post elastic conditions. This results in considerable damage and degradations of members' strength and stiffness, which ultimately

Anurag Sharma

asharma.phd2017.civil@nitrr.ac.in

R. K. Tripathi

rktripathi.ce@nitrr.ac.in

Govardhan Bhat

gov.ce@nitrr.ac.in

1 Department of Civil Engineering, National Institute of Technology Raipur, Raipur, India affects the seismic performance of buildings [6-11]. This leads to assessing and designing of new techniques, which will take care of seismic performance of buildings under severe excitations.

One of the latest techniques developed over the last decades is the Direct-displacement based design (DDBD) method. DDBD approach was first proposed for only RC bridges by Kowalsky et al. (1995) [12], where a single degree of freedom (SDOF) system of a single pier of know mass was proposed to foresee the required secant stiffness for anticipated inelastic displacement. Further, by adopting the same approach Priestley and Kowalsky (2000) [13] proposed DDBD for RC frame buildings. Later, many researchers proposed various modifications for DDBD approach to get the better seismic performance of structures. Sullivan et al. [14] provided reliable code implementation guidelines for a wide range of structures. Pettinga and Priestley (2005) [15] revised DDBD by accounting for higher modes effects for high-rise buildings, resulting in better distribution of lateral forces over the selected RC frame buildings. Moghim and Saadatpour (2008) [16] investigated DDBD design for concrete buildings located in near-fault regions. Khumbhar et al. (2020) [17] studied the different DDBD methods developed by various researchers for low, medium and highrise structures. The study results highlight the importance 
of parabolic displacement profile over linear displacement profile of RC buildings. Many literatures compared FBD and DDBD approaches by comparing various parameters, i.e. displacements, drifts, ductility demands, strain limits, serviceability limits etc., and provides an in-depth knowledge of advantages and disadvantages of both the methods [18-23]. With time DDBD approach gets further extension to different structural systems, i.e. steel frames [24-26], shear walls [27-30] and base isolators [31-33].

The previous study found that a lot of work has been done for the seismic assessment of multi-storied buildings designed by DDBD approach. However, a proper comparison of different multi-storied RC buildings with various configurations but having the same plan area is not much emphasized in the literature in the context of DDBD methodology. Hence, in the present study a comparison is carried out of different RC buildings with various configurations but with the same total plan area designed by the DDBD procedure. For this purpose, four-storey RC buildings designed and detailed for the highest seismic zone (ZoneV) as per relevant Indian standards [1] is considered. Nonlinear dynamic analysis of the selected frames is carried out to investigate the seismic behaviour of frames under earthquake excitations. The influence of DDBD approach in $\mathrm{RC}$ frames is investigated by comparing the final results in terms of base-shear ratio, drift ratios, ductility demands and maximum displacements.

\section{Overview of DDBD methodology for RC buildings}

The fundamentals of DDBD approach have already been discussed in various literatures [13-16]. In this paper, DDBD approach of Priestley et al. (2007) [34] has been followed for designing RC buildings. To have a basic understanding of method a brief outline of the method is explained using Fig. 1. The DDBD method is based on substituting the Multi-degree of freedom (MDOF) system with equivalent-SDOF system representing the characteristics of the real structure as shown in Fig. 1(a). The equivalent-SDOF system is characterised by the effective stiffness corresponding to the desired inelastic displacement response as seen in Fig. 1(b). The properties of an equivalent-SDOF system, namely, design displacement $\left(\Delta_{d}\right)$, effective mass $\left(m_{e}\right)$ and effective height $\left(H_{e}\right)$ are determined with the help of design
Fig. 1 Design steps of DDBD approach [34]. a SDOF Simulation b Effective Stiffness $\left(K_{e}\right) \mathbf{c}$ Equivalent damping Vs Ductility d Design Displacement Spectra

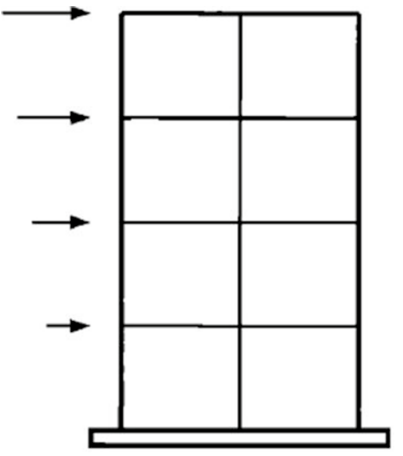

(a) SDOF Simulation

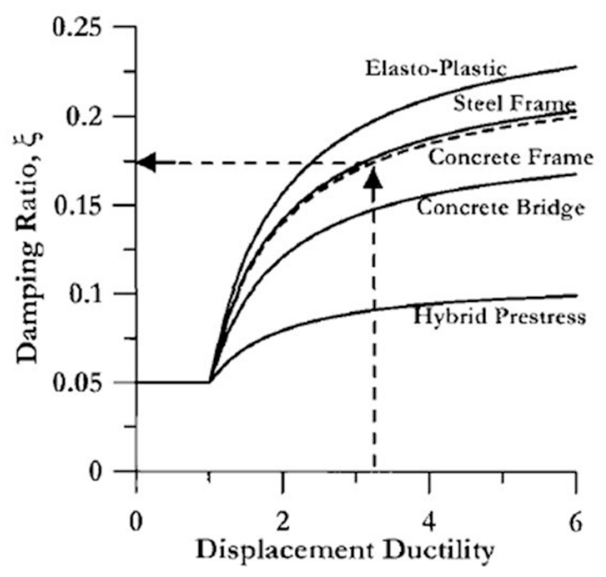

(c) Equivalent damping Vs Ductility
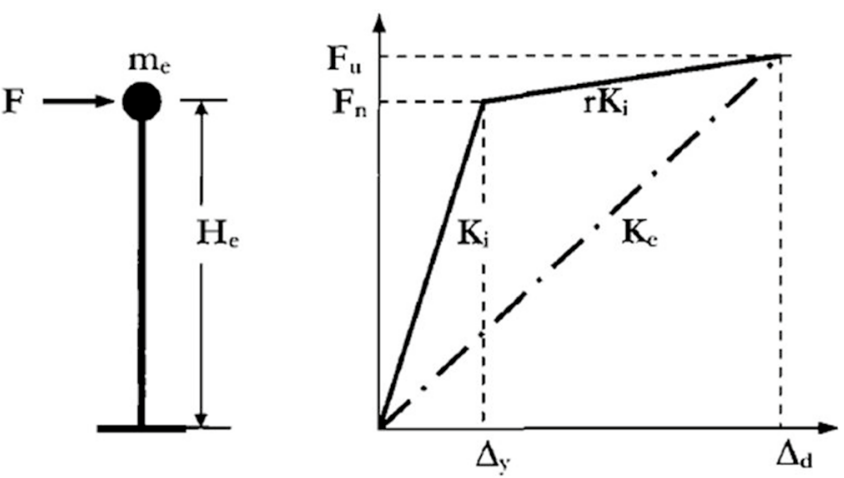

(b) Effective Stiffness $\left(K_{e}\right)$

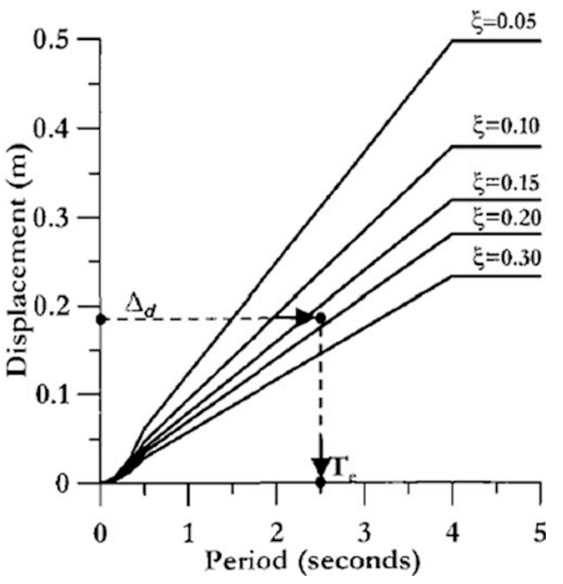

(d) Design Displacement Spectra 
displacement profile. To determine the equivalent viscous damping of an equivalent-SDOF system, design ductility $(\mu)$ is calculated based on design $\left(\Delta_{d}\right)$ and yield $\left(\Delta_{y}\right)$ displacements and a relationship is formed between equivalent viscous damping and calculated design ductility as represented in Fig. 1(c). As illustrated in Fig. 1(d), with known equivalent damping level and calculated design displacement $\left(\Delta_{d}\right)$, effective time period $\left(T_{e}\right)$ of equivalent-SDOF system can be measured. With known time period, effective stiffness $\left(K_{e}\right)$ at maximum displacement can be determined. Finally, the base shear force $\left(V_{b}\right)$ cab be obtained from known $\left(K_{e}\right)$ and $\left(\Delta_{d}\right)$ respectively. Using above base shear forces, dimensions of frame members are determined.

\section{Description and design of selected RC buildings}

The RC buildings considered in this study are typically fourstorey RC frames designed for critical load combinations using the relevant Indian standard codes [35-37]. This study's basic aim is to evaluate the seismic behaviour of RC buildings with distinct configurations but the same total plan area and designed using DDBD approach. Thus, as shown in Fig. 2, structural irregularities are brought by changing the number of bays and span length in X- and Y-directions. For instance, $\mathrm{X} 4-\mathrm{Y} 4$ (Plan 1) represents the RC building having three spans in longitudinal direction and three spans in transverse direction of span length of $4.0 \mathrm{~m}$ each as depicted in Fig. 2(a). Similarly, Fig. 2(b) represents the plan X6-Y4 (Plan 2) having three spans in X-direction with a span length of $6.0 \mathrm{~m}$ and two spans in Y-direction with a span length of $4.0 \mathrm{~m}$ each. On a similar note, plan X4.8-Y5 (Plan 3) is shown in Fig. 2(c) with three spans in X-direction of span length $4.8 \mathrm{~m}$ and two spans in Y-direction of $5.0 \mathrm{~m}$ span length. Therefore, the configurations of buildings are chosen in such a way that the total plan area remains the same as $144 \mathrm{~m}^{2}$. The storey height is kept the same at $3.0 \mathrm{~m}$ for all floor levels of RC buildings.

Material properties are adopted as per India's common practices. M25 grade of concrete is considered having modulus of elasticity $\left(E_{c}\right)$ of $25,000 \mathrm{MPa}$ and cube strength $\left(f_{c k}\right)$ of $25 \mathrm{MPa}$. Also, Fe-415 reinforcing steels are used with yield strength $\left(f_{y}\right)$ of $415 \mathrm{MPa}$, respectively. The RC buildings considered are assumed to be located in India's highest seismic-Zone (V) as per IS 1893 (2016) [1]. The RC buildings are designed using DDBD approach guidelines given by Priestley et al. (2007) [34], as discussed in the previous section. The outline of DDBD parameters is summarised in Table 1 . The dimensions of beams and columns are determined from DDBD approach in such a way that maximum steel content is less than $4 \%$ in both beams and columns [38]. Table 2 outlines the final dimensions of section members for all RC buildings. The target drift of $(\theta=2 \%)$ has been selected for life-safety criteria limit as recommended in FEMA 356 (2000) [39]. Figure 3 and Table 3 give insight details of all performance levels and their acceptability drift criteria.

\section{Ground motion records for Non-linear Time History Analysis (NTHA)}

The seismic behaviour of the RC buildings is well determined by NTHA. NTHA is one of the most powerful techniques for achieving the performance of the $\mathrm{RC}$ buildings under design seismic intensity. Therefore, selection of appropriate ground motions becomes most important, since the random nature of ground motions may cause uncertainties in the response of structure [40, 41]. According to ASCE 7-16 (2016) [4] and FEMA P695 (2009) [42], both natural and synthetic ground motions can be used for evaluation of building performances. Also, the guidelines of FEMA P695 (2009) [42] and Reyes and Kalkan (2012) [43] suggested using a minimum of seven earthquakes records for precise assessments. Therefore, to have a proper evaluation of selected RC frames, a suite of two sets of ground motions is selected from Center for Engineering Strong Motion Data (CESMD) website [44]. The first set (SET-I) of seven ground motions is selected from Indian regions. The selecting parameter of (SET - I) ground motions are - (a) ground motions are far-field earthquakes, hypo-central distance is more than $10 \mathrm{~km}$ and (b) have a frequency range of $0 \mathrm{~Hz}$ to $30 \mathrm{~Hz}$ as described in Table 4. Whereas, second set (SETII) of seven ground motions recorded from other regions are collected based on following conditions - (a) magnitude should be more than 6.5 in Richter scale, (b) distance from the source to site should be more than $10 \mathrm{~km}$ and (c) frequency should be in the range of $0 \mathrm{~Hz}$ to $50 \mathrm{~Hz}$. Table 5 provides the full detail of these selected ground motion records. Both sets of ground motions are made compatible with the site condition of Zone- $\mathrm{V}$, medium soil condition of Indian region (PGA-0.36) as per Indian standard IS 1893 (2016) [1] using a SeismoMatch software [45]. Figure 4 represents the response spectra of ground motions complemented with the target spectrum.

\section{Evaluation of selected RC frames using NTHA}

In this study, the inelastic behaviour of low-rise RC frame buildings designed using DDBD procedure is assessed using non-linear time history analysis (NTHA). Buildings with different structural configurations are selected and analysis is performed in SAP2000 V.20 structural analysis software [46]. P- $\Delta$ effects are also taken into consideration. All RC 

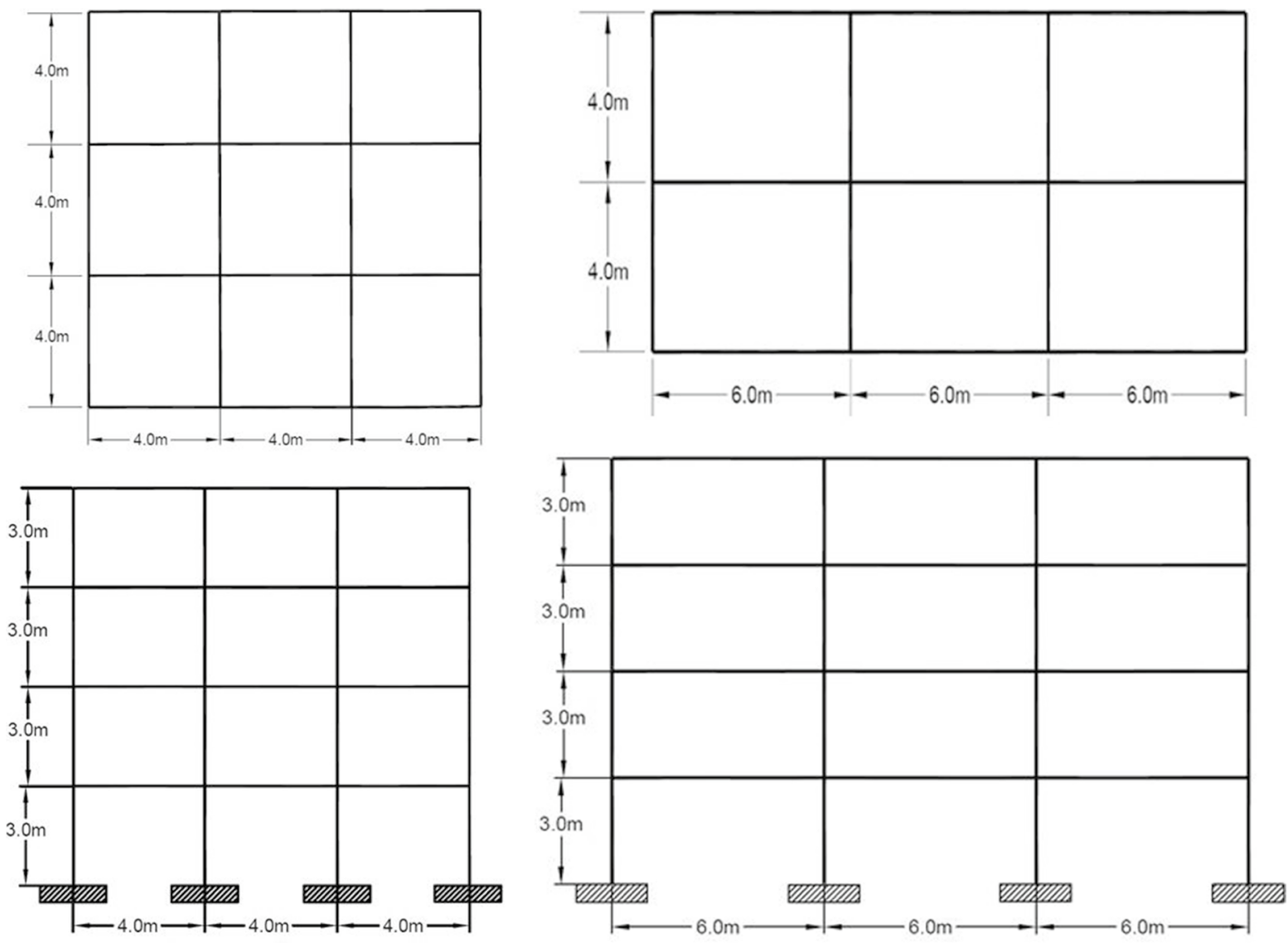

(a) Plan and front elevation view of X4-Y4 (Plan 1)

(b) Plan and front elevation view of X6-Y4 (Plan 2)
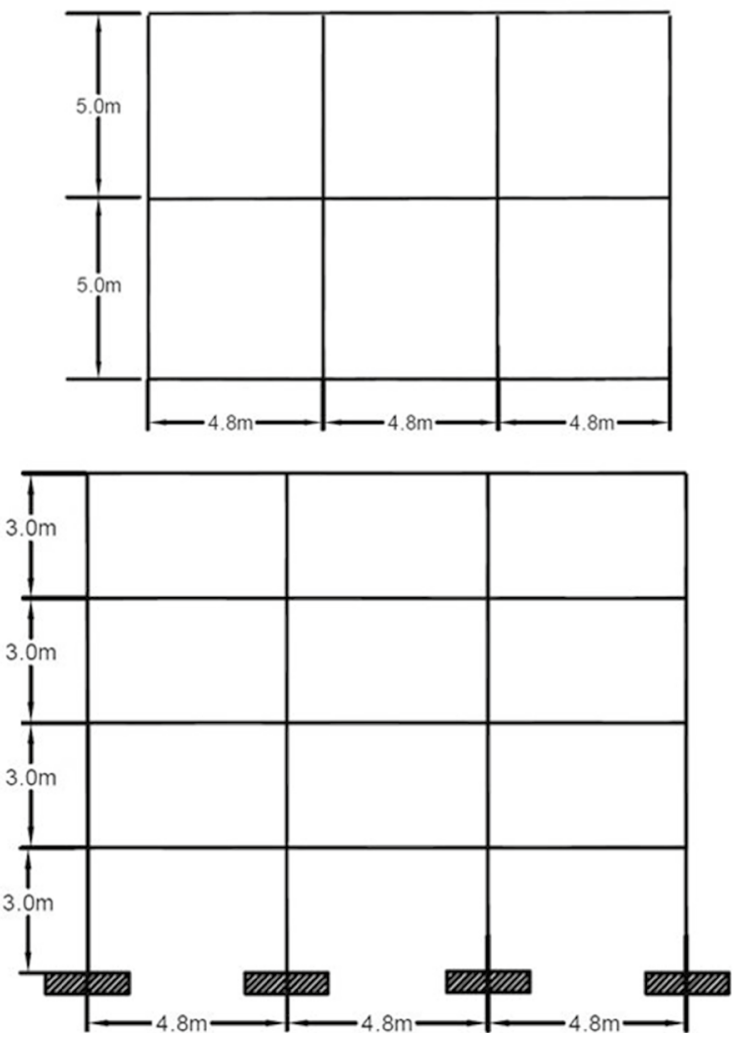

(c) Plan and front elevation view of X4.8-Y5 (Plan 3) 
4 Fig. 2 Geometry of RC buildings. a Plan and front elevation view of X4-Y4 (Plan 1) b Plan and front elevation view of X6-Y4 (Plan 2) c Plan and front elevation view of X4.8-Y5 (Plan 3)

buildings are designed for $2 \%$ permissible drift as per FEMA 356 (2000) [39]. The storey shear ratio is presented in Fig. 5. The normalised storey height $\left(H_{i} / H_{n}\right)$ in percentage is represented in X-axis, were $H_{i}$ is storey height of the particular floor and $H_{n}$ is total storey height. Whereas, in Y-axis a normalised storey shear ratio is expressed. Storey shear $(\mathrm{V})$ is normalised with respect to seismic weight $(\mathrm{W})$ of the structure. Further, note that FBD procedure is also adopted for all different structural configurations RC buildings. Since, their storey shear ratio is near and almost the same for all plans, so only for one building plan FBD result is shown in Fig. 5. It is perceived from Fig. 5 that, at ground storey level all DDBD models except Plan X4-Y4 estimates higher design base shear than FBD building. But, as the storey height increases storey shear decreases for all RC buildings. Also, all DDBD RC models in higher storeys over-estimate the storey shear than FBD model. Plan X4-Y4, X6-Y4 and X4.8Y5 estimate around $18 \%, 45 \%$ and $37 \%$ higher values than FBD building. Among all DDBD RC buildings, plan X6-Y4 have the highest base shear value and is $45 \%$ higher than the building designed by FBD approach. Whereas plan X4-Y4 yields at lower base shear but has the highest ductility than other floor plans as depicted in Table 1. From Fig. 5 result, it can be concluded that the low-rise RC buildings designed by DDBD for $2 \%$ target drift are stiffer and have high initial stiffness and attract higher floor acceleration than buildings designed by FBD method [19, 21].

Various researchers have confirmed that the Inter-Storey Drift Ratio (ISDR) and inelastic storey displacement obtained from NTHA as indicators of damage in RC frame buildings [23, 28, 34, 47]. Thus, the performance of various RC buildings designed by DDBD approach under earthquake excitation are evaluated based on ISDR and storey displacement.
The mean seismic response of ground motions obtained from NTHA are then compared with the target performance level which in our case is $2 \%$ drift level. Figures 6 and 7 represents the storey displacement and drift values of plan X4-Y4 for both sets of ground motions. The results shown in Figs. 6 and 7 highlights that maximum storey drift is obtained for GM_07 (Uttarkashi) and minimum from GM_02 (ChamoliJoshimath) for SET-I ground motions. Whereas, for SET-II ground motions, maximum is obtained for GM_11 (Northridge) and minimum for GM_12 (Hollister). The mean drift value obtained from SET-I and SET-II ground motions are about $83 \%$ and $82 \%$ less than the target drift of $2 \%$. Similarly, the comparative plots of inelastic storey displacement and drifts of plan X6-Y4 are shown in Figs. 8 and 9. It can be found from Figs. 8 and 9 that the mean drift values under selected earthquakes are close to the target drift when compared to other plans chosen with variations of $73 \%$ and $74 \%$ for SET-I and SET-II ground motions. GM_06 (India-Burma Border-Silchar) and GM_10 (Loma-Prieta) show maximum drift, whereas minimum drift can be noticed for GM_01 (Chamoli - Ghansiali) and GM_12 (Hollister) for model X6-Y4, respectively. Further, inelastic storey displacement and drifts obtained from NTHA of plan X4.8-Y5 are mentioned in Figs. 10 and 11 . The mean inter-storey drifts obtained from NTHA are approximately $81 \%$ and $80 \%$ less than that of target drift for SET-I and SET-II ground motions. Also, Figs. 12 and 13 represents the average of the storey displacement and drifts recorded from NTHA for all plans. One can note that both the displacements and drifts are maximum for plan X6-Y4 and minimum for plan X4-Y4 for both sets of ground motions.

From the above discussions of results, it is apparent that all different plans are able to satisfy the target drift of $2 \%$ for both sets of ground motions and lead to the acceptable dynamic behaviour of $\mathrm{RC}$ frame buildings. The results suggest that the DDBD design method has successfully controlled the response of the structure. It can also be noted from all figures that, the design drifts are maximum at
Table 1 DDBD parameters of selected RC buildings

\begin{tabular}{lccc}
\hline & Different Plans & & \\
\cline { 2 - 4 } & X4-Y4 & X6-Y4 & X4.8-Y5 \\
\hline Design Displacement $\Delta_{d}(\mathrm{~m})$ & 0.1752 & 0.1754 & 0.1754 \\
Effective Height $H_{e}(\mathrm{~m})$ & 8.7597 & 8.7729 & 8.7686 \\
Effective Mass $m_{e}(\mathrm{t})$ & 388.44 & 360.80 & 359.15 \\
Yield Displacement $\Delta_{y}(\mathrm{~m})$ & 0.0909 & 0.1365 & 0.1092 \\
Ductility $\mu\left(\Delta_{d} / \Delta_{y}\right)$ & 1.92 & 1.28 & 1.60 \\
Effective Period $T_{\text {eff }}(\mathrm{s})$ & 2.28 & 1.87 & 2.0 \\
Equivalent Viscous Damping $(\%)$ & 13.66 & 8.99 & 11.79 \\
Effective Stiffness $K_{\text {eff }}(\mathrm{kN} / \mathrm{m})$ & 2993.20 & 4133.09 & 3596.70 \\
Base Shear Force $V_{\text {base }}(\mathrm{kN})$ & 524.39 & 725.18 & 630.76 \\
\hline
\end{tabular}


Table 2 Sectional details of columns and beams

\begin{tabular}{|c|c|c|c|c|c|c|c|c|c|c|}
\hline \multirow[t]{2}{*}{ Plan No } & \multirow[t]{2}{*}{ Plans } & \multicolumn{2}{|c|}{$\begin{array}{l}\text { No. of bays } \\
\text { in both } \\
\text { directions }\end{array}$} & \multirow[t]{2}{*}{$\begin{array}{l}\text { Storey } \\
\text { Height (m) }\end{array}$} & \multicolumn{2}{|c|}{$\begin{array}{l}\text { Span in both } \\
\text { directions } \\
\text { (m) }\end{array}$} & \multicolumn{2}{|c|}{ Beam (m) } & \multicolumn{2}{|c|}{ Column (m) } \\
\hline & & $X$ & Y & & $X$ & $\mathrm{Y}$ & Width & Depth & Width & Depth \\
\hline Plan 1 & $\mathrm{X} 4-\mathrm{Y} 4$ & 3 & 3 & 3.0 & 4 & 4 & 0.35 & 0.4 & 0.4 & 0.4 \\
\hline Plan 2 & $\mathrm{X} 6-\mathrm{Y} 4$ & 3 & 2 & 3.0 & 6 & 4 & 0.35 & 0.4 & 0.4 & 0.5 \\
\hline Plan 3 & X4.8-Y5 & 3 & 2 & 3.0 & 4.8 & 5 & 0.35 & 0.4 & 0.45 & 0.45 \\
\hline
\end{tabular}

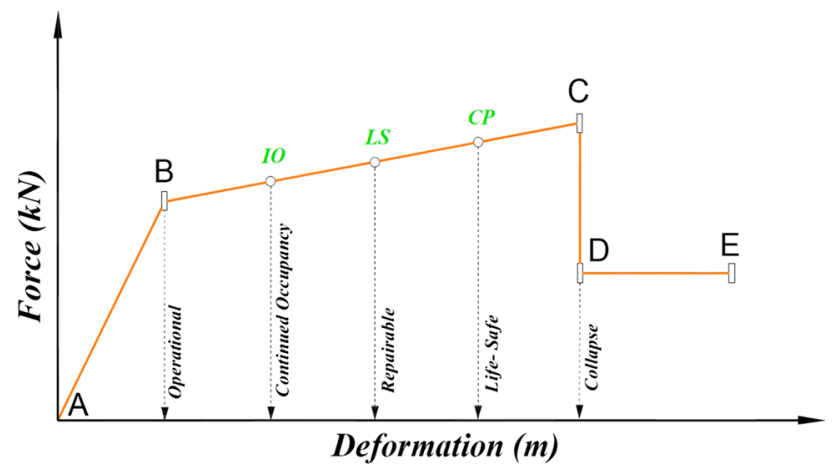

Fig. 3 Typical Performance levels and Force-Deformation relationship

bottom storeys and with an increase in storey level drifts gradually decreases and tend to be lower at the top stories for all the RC plans. These results confirm that ground motions tend to deflect RC frames in shear mode, resulting in higher drifts at the bottom than top stories [48, 49].
Further, one can also note that the inelastic displacement profiles and inter-storey drift profiles obtained from NTHA of all plans representing low-rise building designed using DDBD approach provides a conservative design. The conservative results could be due to the parametric and empirical nature of DDBD's equations that induce errors. Some of the RC members were assigned a higher capacity than required as it is highly impractical to design each member according to its demand [50,51]. Also, the DDBD design suggested by Priestley et al. (2007) [34] for RC frame buildings, uses a normalised displacement profile expression which was developed only based on non-linear analysis results of the RC-tube frames. For RC structures with various configurations, no. of stories, seismic site location, soil condition, design limit states etc., the design displacement profile may vary according to requirements. However, to generalise this conclusion for low-rise RC buildings, more non-linear analysis is required by varying PGA values. Overall, from NTHA results, the current DDBD method can satisfy the performance objective for all selected RC frames buildings.

Table 3 Description of acceptable drift ratio of performance levels from FEMA 356

\begin{tabular}{lll}
\hline Performance Levels & Damage-Level & $\begin{array}{l}\text { Acceptable } \\
\text { drift ratio } \\
(\%)\end{array}$ \\
\hline Immediate Occupancy (IO) & No risk of life, facilities continuously operational with minor damage & $\begin{array}{l}1 \% \\
\text { Life Safety (LS) }\end{array}$ \\
Collapse Prevention (CP) & Safety of life is essentially protected, but damage is of moderate to severe level & $2 \%-2.5 \%$ \\
& Safety of life is at risk, where damage is of high severity level and structure is in danger & $>2.5 \%$
\end{tabular}

Table 4 Selected Indian ground motion records (SET - I)

\begin{tabular}{llllll}
\hline Reference No & Name of Event & Event Date \& Year & Record Station & Time Step (s) & Duration (s) \\
\hline GM_01 & Chamoli & $29 / 03 / 1999$ & Ghansiali, India & 0.02 & 26.24 \\
GM_02 & Chamoli & $29 / 03 / 1999$ & Joshimath, India & 0.02 & 24.98 \\
GM_03 & NE-India & $10 / 09 / 1986$ & Saitsama, India & 0.02 & 20.60 \\
GM_04 & India-Burma Border & $06 / 05 / 1995$ & Diphu, India & 0.02 & 28.54 \\
GM_05 & India-Burma Border & $08 / 05 / 1997$ & Doloo, India & 0.02 & 27.38 \\
GM_06 & India-Burma Border & $08 / 05 / 1997$ & Silchar, India & 0.02 & 26.88 \\
GM_07 & Uttarkashi & $20 / 10 / 1991$ & Tehri, India & 0.02 & 31.92 \\
\hline
\end{tabular}


Table 5 Selected other ground motion records from different regions $(\mathrm{SET}-\mathrm{II})$

\begin{tabular}{llllll}
\hline Reference No & Name of Event & Event Date \& Year & Record Station & Time Step (s) & Duration (s) \\
\hline GM_08 & Imperial Valley & $15 / 10 / 1979$ & USGS & 0.01 & 39.48 \\
GM_09 & Friuli & $06 / 06 / 1976$ & Tolmezzo & 0.01 & 36.62 \\
GM_10 & Loma-Prieta & $18 / 10 / 1989$ & GDMG & 0.01 & 39.90 \\
GM_11 & Northridge & $17 / 01 / 1994$ & CDMG & 0.01 & 39.88 \\
GM_12 & Hollister & $09 / 04 / 1961$ & USGS & 0.01 & 39.93 \\
GM_13 & Kocaeli & $17 / 08 / 1999$ & Yarimca & 0.01 & 34.96 \\
GM_14 & Kobe & $16 / 01 / 1995$ & Kakogama & 0.01 & 40.90
\end{tabular}

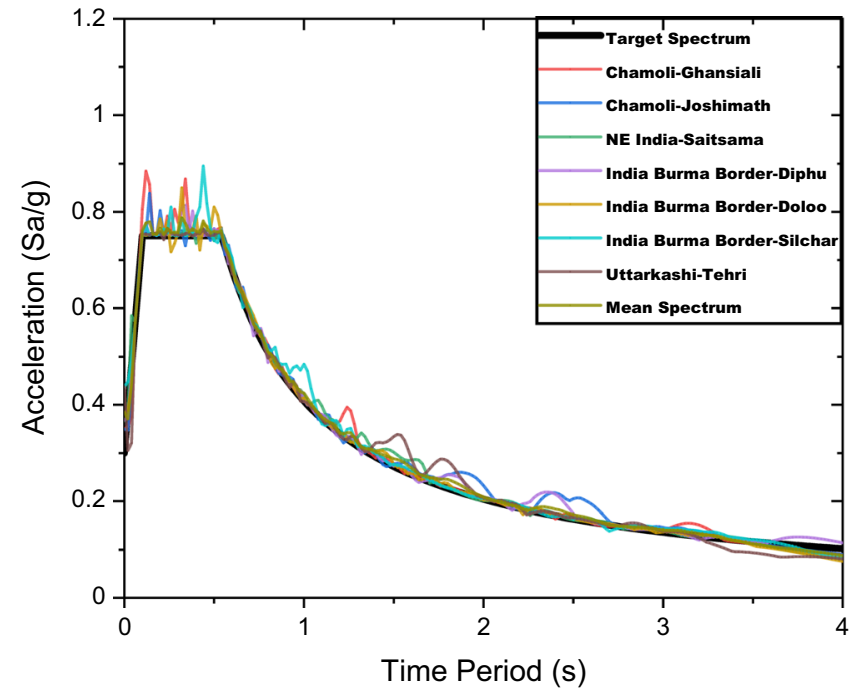

(a) Set - I Ground Motions

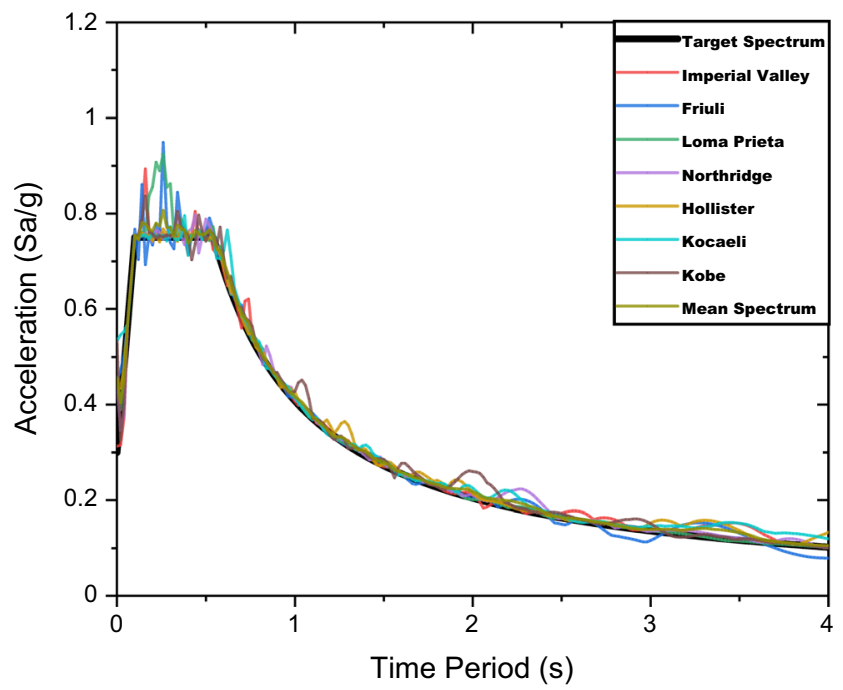

(b) Set - II Ground Motions

Fig. 4 Compatible response spectra of both sets of ground motions a Set-I Ground Motions b Set - II Ground Motions

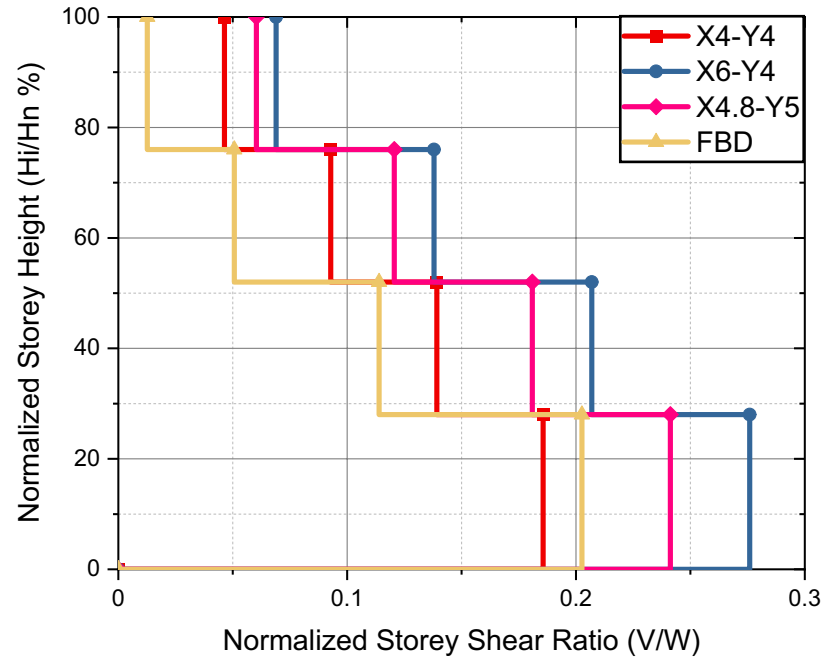

Fig. 5 Storey shear ratio for all DDBD and FBD models

\section{Conclusions}

In this research, the established DDBD methodology is applied to low-rise RC frame buildings located in seismic regions of Indian Terrains. Three different plans are selected based on different structural configurations but with the same total plan area $\left(144 \mathrm{~m}^{2}\right)$. The inelasticbehaviour of RC buildings are investigated through the non-linear time history analysis (NTHA) using fourteen strong ground motions. These ground motions are divided into two different sets based on various parameters. A significant variation in base shear is seen between the RC buildings designed by DDBD approach. Also, the buildings designed by DDBD method have relatively higher base shear than the FBD approach, resulting in the design of stiffer structures. The performance of RC buildings in terms of storey displacement and ISDR satisfies the target objective of $2 \%$ drift level and are well-under controlled. 


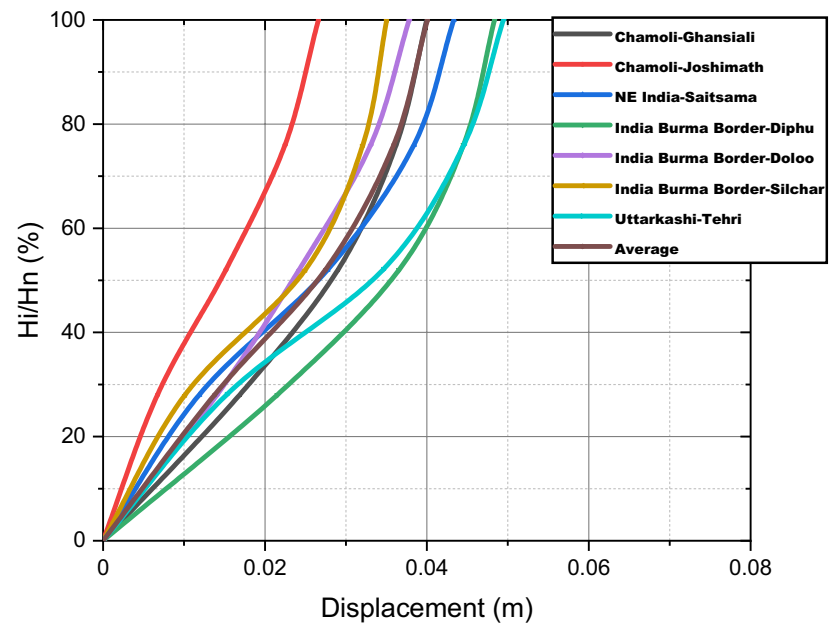

(a) Storey-Displacement (m)

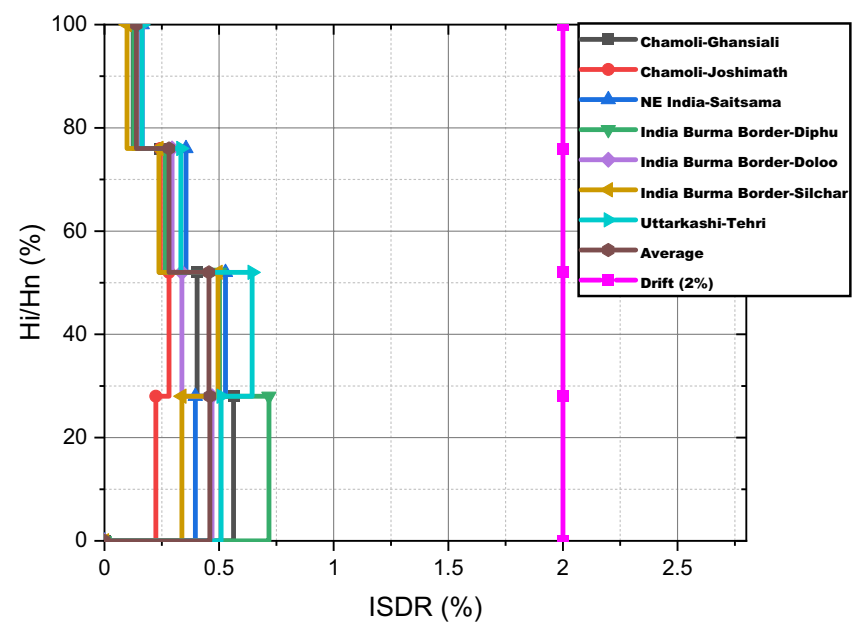

(b) $\operatorname{ISDR}(\%)$

Fig. 6 Representation of storey displacement and ISDR of plan X4-Y4 for SET-I ground motions a Storey-Displacement (m) b ISDR (\%)

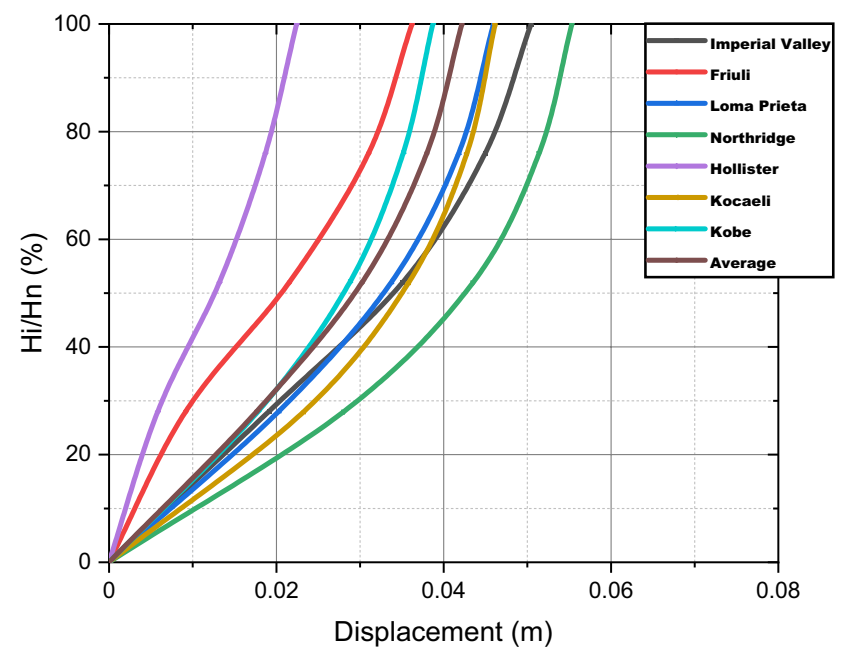

(a) Storey-Displacement (m)

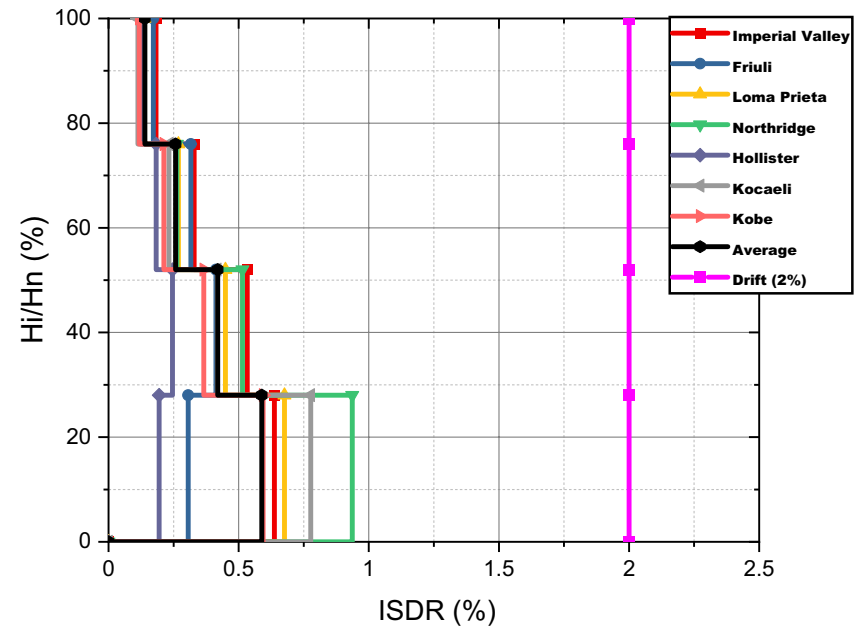

(b) $\operatorname{ISDR}(\%)$

Fig. 7 Representation of storey displacement and ISDR of plan X4-Y4 for SET-II ground motions a Storey-Displacement (m) b ISDR (\%)

The maximum displacements and drifts are recorded for plan X6-Y4, whereas minimum storey displacements and drifts are observed in plan X4-Y4. However, it is found that all RC buildings for all different plans provide a conservative design, where the mean of inter-storey drift obtained from NTHA is approximately $73 \%-83 \%$ less than that of target permissible drift of (2\%). Overall, the comparison indicates that the current DDBD approach leads to reasonable results for low-rise RC frame buildings and aims to provide a reliable structural design that satisfies the target performance criteria. It can also be stated that this study has a significant importance in existing construction practices in India, where the majority of RC buildings are still designed using FBD methods, especially in earthquake-prone areas. Further, the conclusions of the present study are limited by the fact that only low-rise RC 


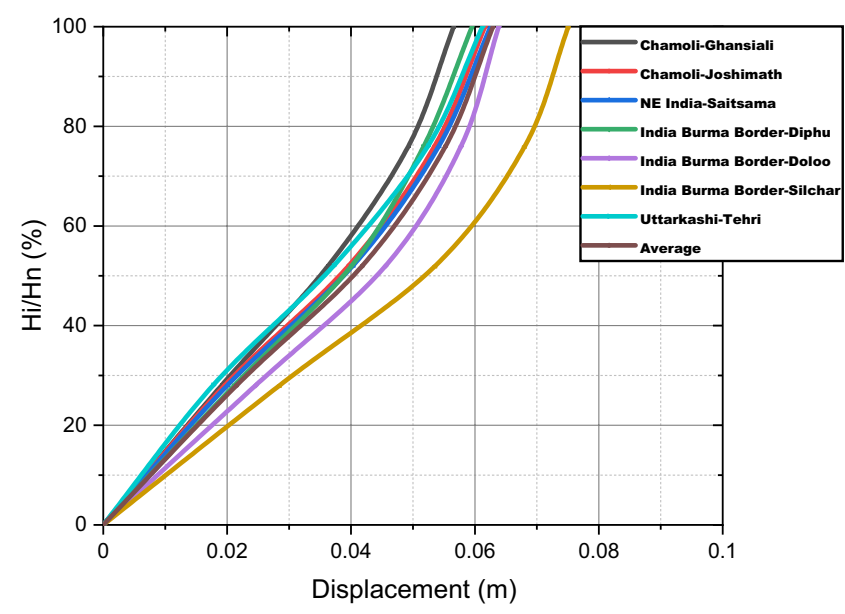

(a) Storey-Displacement (m)

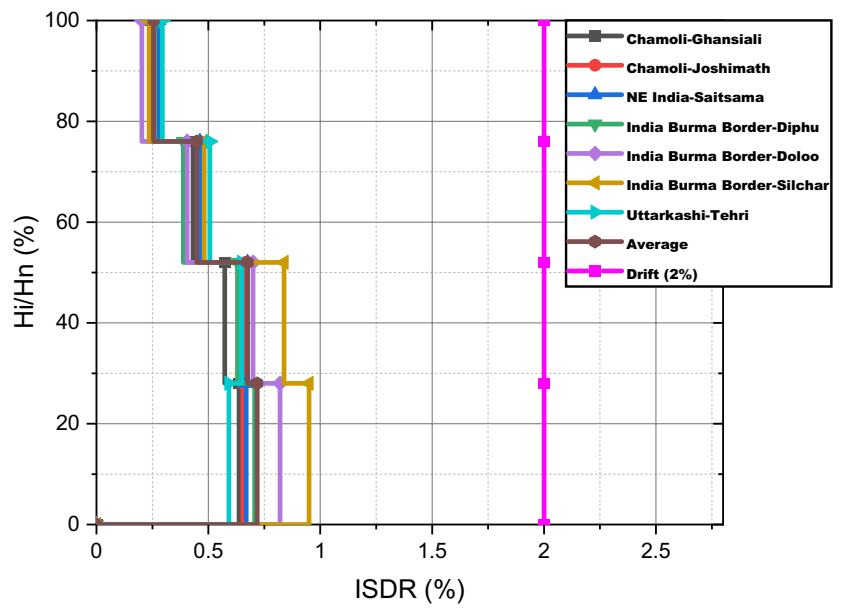

(b) $\operatorname{ISDR}(\%)$

Fig. 8 Representation of storey displacement and ISDR of plan X6-Y4 for SET-I ground motions a Storey-Displacement (m) b ISDR (\%)

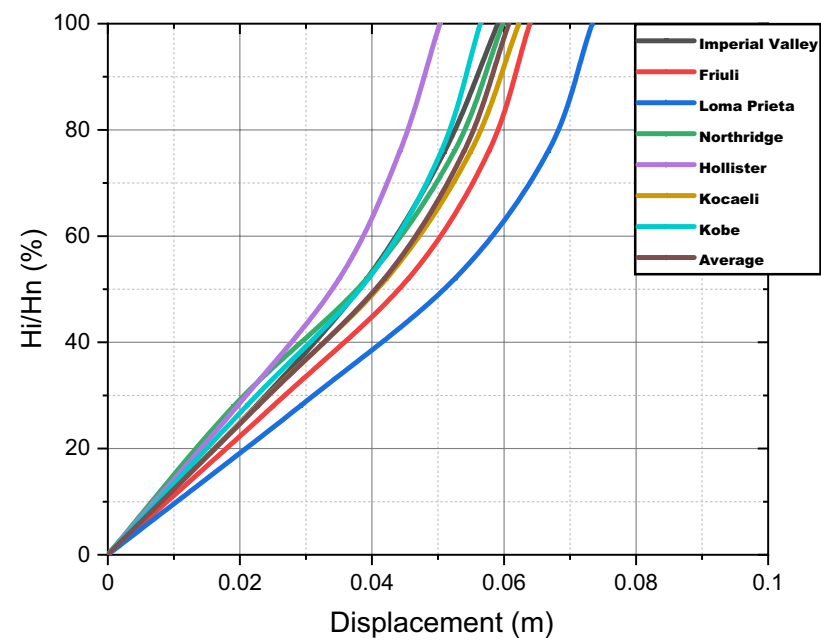

(a) Storey-Displacement (m)

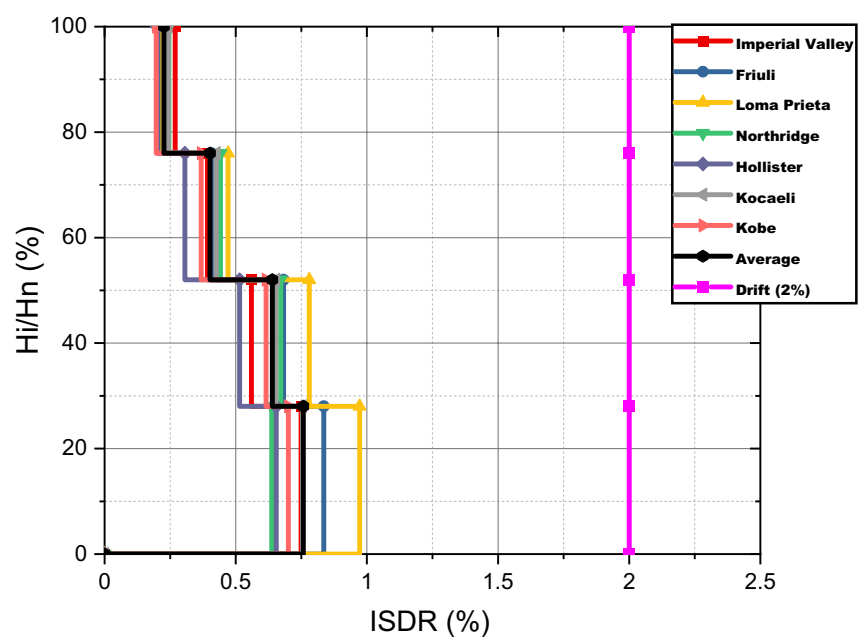

(b) $\operatorname{ISDR}(\%)$

Fig. 9 Representation of storey displacement and ISDR of plan X6-Y4 for SET-II ground motions a Storey-Displacement (m) b ISDR (\%) 


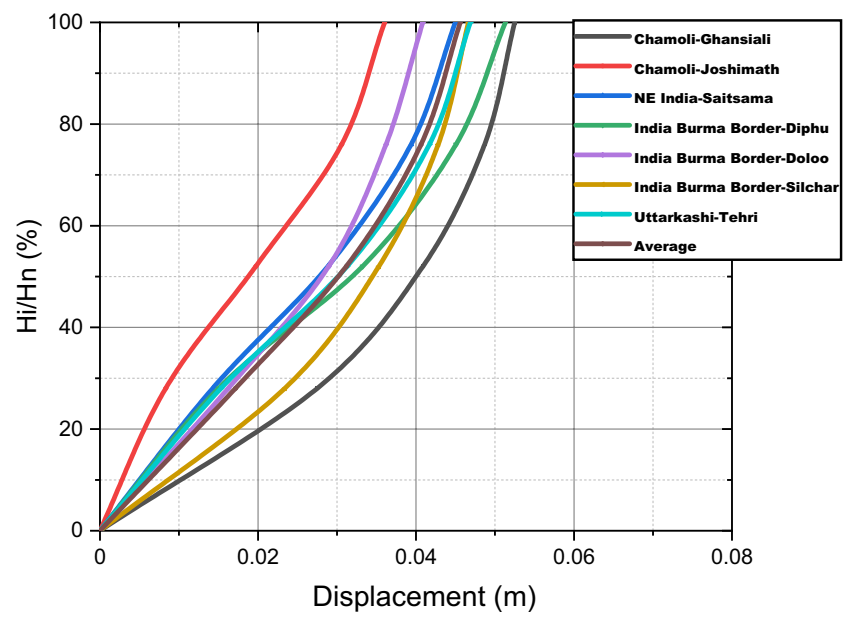

(a) Storey-Displacement (m)

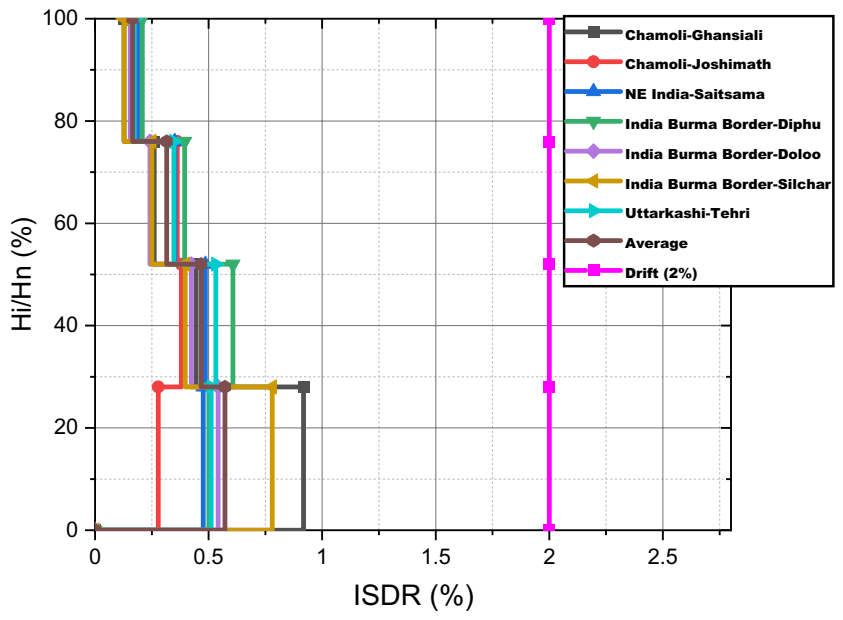

(b) ISDR (\%)

Fig. 10 Representation of storey displacement and ISDR of plan X4.8-Y5 for SET-I ground motions a Storey-Displacement (m) b ISDR (\%)

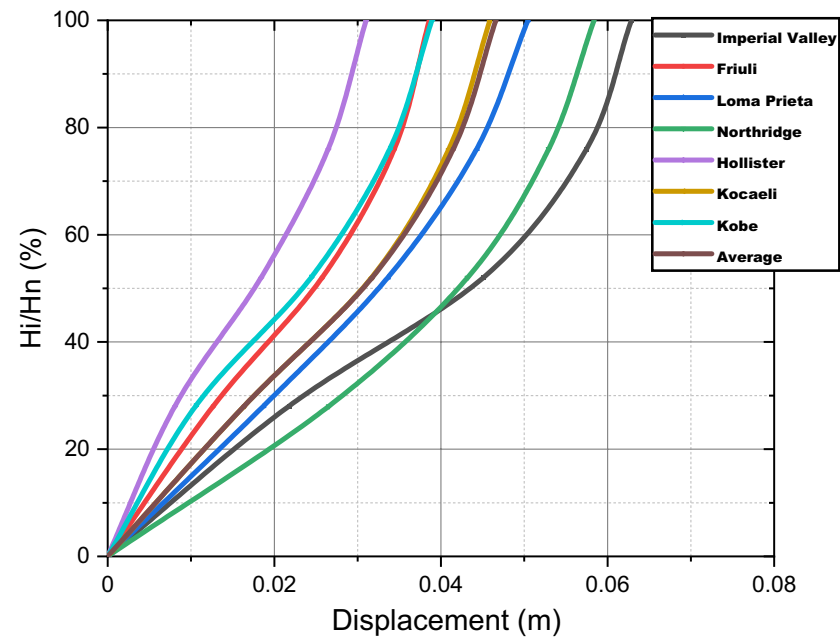

(a) Storey-Displacement (m)

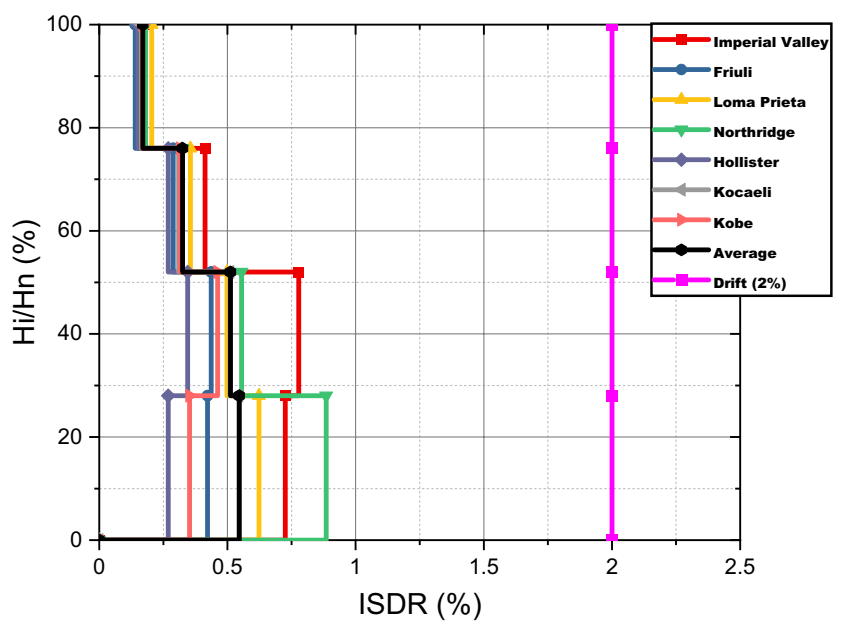

(b) $\operatorname{ISDR}(\%)$

Fig. 11 Representation of storey displacement and ISDR of plan X4.8-Y5 for SET-II ground motions a Storey-Displacement (m) b ISDR (\%) 


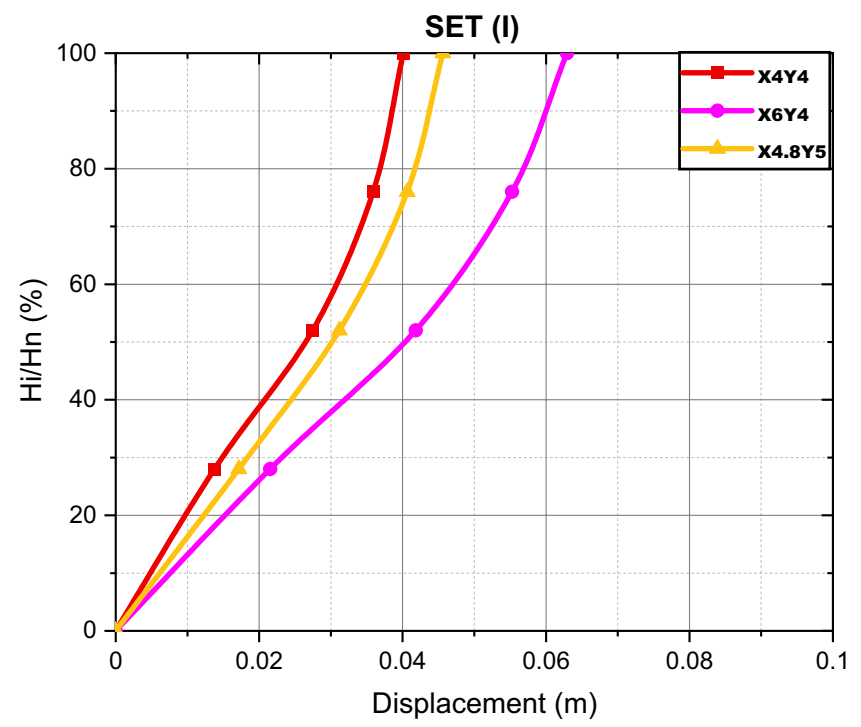

(a) Storey-Displacement (m)

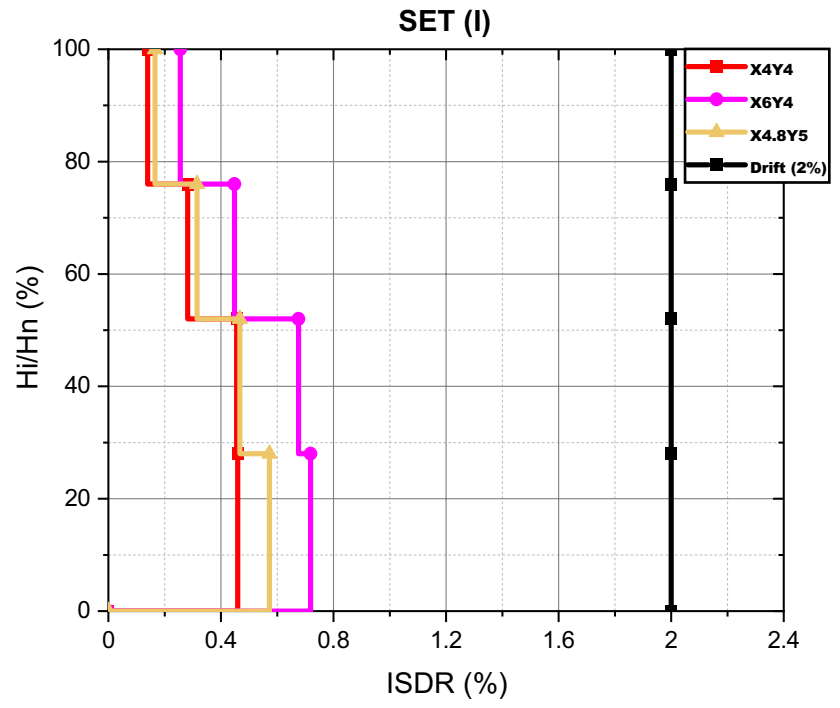

(b) $\operatorname{ISDR}(\%)$

Fig. 12 Representation of mean storey displacement and ISDR of all plans for SET-I ground motions a Storey-Displacement (m) b ISDR (\%)

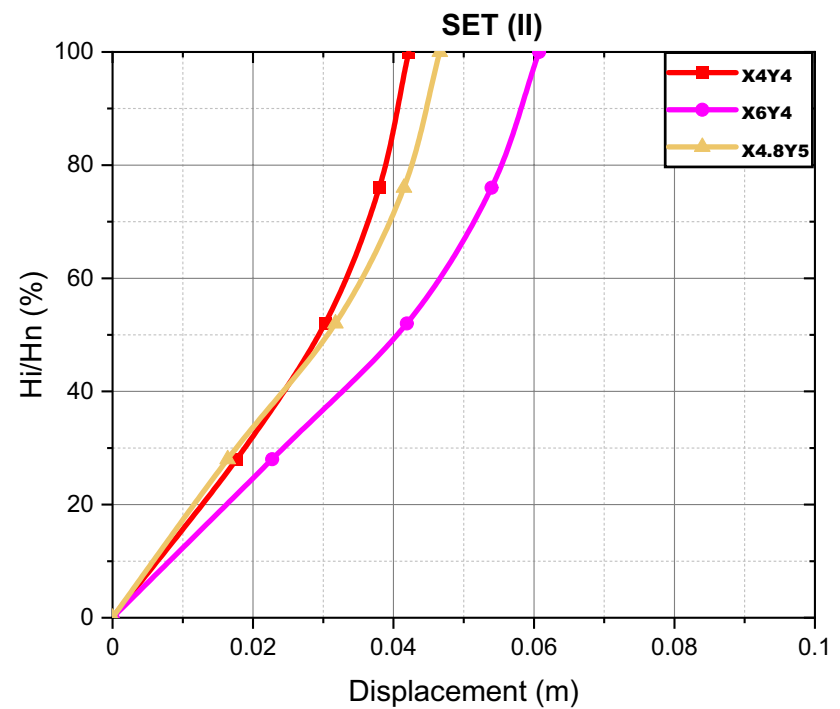

(a) Storey-Displacement (m)

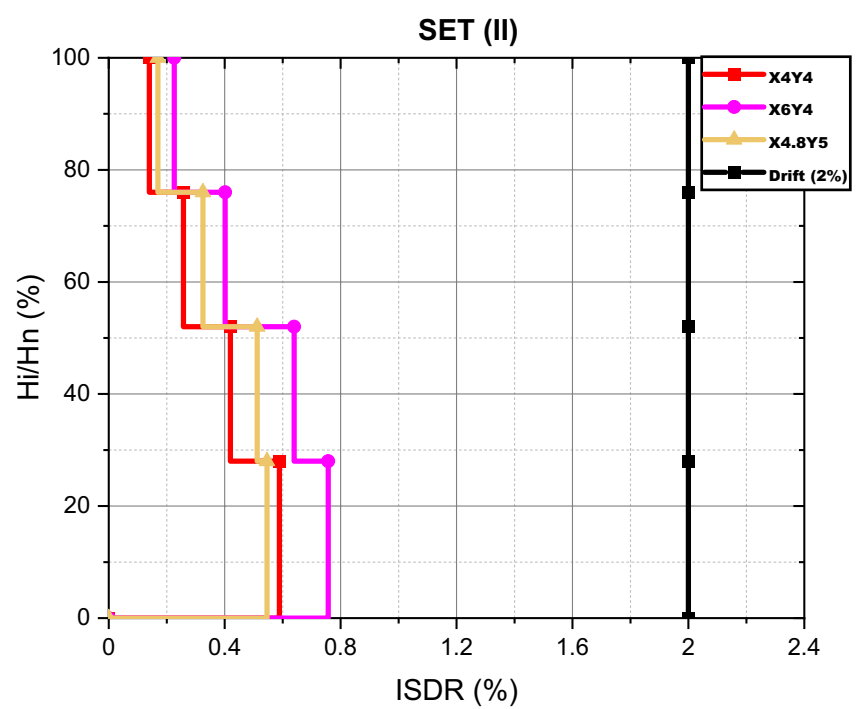

(b) $\operatorname{ISDR}(\%)$

Fig. 13 Representation of mean storey displacement and ISDR of all plans for SET-II ground motions a Storey-Displacement (m) b ISDR (\%)

frame buildings are considered, as a possibility to expand the work for mid-rise and high-rise RC frame buildings.

Acknowledgements The authors are very grateful to Ministry of Education, New Delhi, India and National Institute of Technology Raipur for their continuous motivation, support and guidance to carry out this work.

\section{Declarations}

Conflict of interest There is no Conflict of Interest in the present paper.

\section{References}

1. IS 1893 (2016) Criteria for earthquake resistant design of structures, part-1 general provisions and building. Bureau of Indian standards, New Delhi

2. Standard No. 2800 (2014) Iranian code of practice for seismic resistance design of buildings. Building and Housing Research Center, Tehran

3. European Committee for Standardization (CEN), EN 1998-1:2004 (2004) Eurocode 8, Design of structures for earthquake resistance, part 1: general rules, seismic actions and rules for buildings. CEN, Brussels 
4. ASCE 7-16 (2016) Minimum design loads and associated crietria for buildings and other structures. American Society of Civil Engineers (ASCE/SEI 7-16), Reston

5. National Research Council of Canada (NRCC) (2015) National building code of Canada 2015. Associate Committee on the National Building Code, Ottawa

6. Paulay T, Priestley MJN (1992) Seismic design of reinforced concrete and masonry buildings. Wiley-Interscience Publication, New York

7. Panagiotakos TB, Fardis MN (2001) A displacement-based seismic design procedure for RC buildings and comparison with EC8. Earthq Eng Struct Dynam 30(10):1439-1462. https://doi.org/10. 1002/eqe.71

8. Choudhury S, Singh SM (2013) A unified approach to performance-based design of RC Frame Buildings. J Inst Eng India Ser A 94:73-82. https://doi.org/10.1007/s40030-013-0037-8

9. Gamit K, Amin JA (2021) Drift and response reduction factor of RC frames designed with DDBD and FBD approach. $\mathrm{J}$ Inst Eng India Ser A 102:137-151. https://doi.org/10.1007/ s40030-020-00488-8

10. Chaudhary AK, Choudhury S (2020) Performance of RC Frame Base-Isolated Building with Geotextile as Isolator Using UPBD Method. J Inst Eng India Ser A 101:117-126. https://doi.org/10. 1007/s40030-019-00421-8

11. Dalal SP, Dalal P (2021) Strength, deformation and fragility assessment of reinforced concrete moment resisting frame designed by force based design and the performance based plastic design method for seismic loads. Structures 29:1154-1164. https://doi.org/10.1016/j.istruc.2020.11.029

12. Kowalsky MJ, Priestley MJN, MacRae GA (1995) Displacementbased design of RC bridge columns in seismic regions. Earthquake Eng Struct Dynam 24(12):1623-1643. https://doi.org/10. 1002/eqe.4290241206

13. Priestley MJN, Kowalsky MJ (2000) Direct displacement-based seismic design of concrete buildings. Bull N Z Soc Earthq Eng 33(4):421-444

14. Sullivan TJ, Priestley MJN, Calvi GM (2012) A model code for the displacement-based seismic design of structures, DBD12. IUSS Press, Pavia

15. Pettinga JD, Priestley MJN (2005) Dynamic behaviour of reinforced concrete frames designed with direct displacement-based design. J Earthq Eng 9(2):309-330. https://doi.org/10.1142/S1363 246905002419

16. Moghim F, Saadatpour MM (2008) The applicability of direct displacement-based design in designing concrete buildings located in near-fault regions. Proceedings of 14th World Conference on Earthquake Engineering, October 12-17, Beijing, China

17. Kumbhar OG, Kumar R, Noroozinejad Farsangi E (2020) Investigating the efficiency of DDBD approaches for RC buildings. Structures 27:1501-1520. https://doi.org/10.1016/j.istruc.2020. 07.015

18. Sullivan TJ, Civil P (2013) Highlighting differences between force-based and displacement-based design solutions for reinforced concrete frame structures. Struct Eng Int 23(2):122-131. https://doi.org/10.2749/101686613X13439149156958

19. Vidot-Vega AL, Kowalsky MJ (2013) Drift, strain limits and ductility demands for RC moment frames designed with displacement-based and force-based design methods. Eng Struct 51:128-140. https://doi.org/10.1016/j.engstruct.2013.01.004

20. Muljati I, Asisi F, Willyanto K (2015) Performance of force based design versus direct displacement based design in predicting seismic demands of regular concrete special moment resisting frames. Procedia Engineering 125:1050-1056. https://doi.org/10.1016/j. proeng.2015.11.161

21. Sil A, Das G, Hait, P (2018) Characteristics of FBD and DDBD techniques for SMRF buildings designed for seismic zone-V in India. J Build Pathol Rehabil. 4 (1). https://doi.org/10.1007/ s41024-018-0040-6

22. Qammer SS, Dalal SP, Dalal P (2019) Displacement-based design of rc frames using design spectra of Indian code and its seismic performance evaluation. J Inst Eng India Ser A 100:367-379. https://doi.org/10.1007/s40030-019-00373-z

23. Sharma A, Tripathi RK, Bhat G (2020) Seismic assessment of $\mathrm{RC}$ building frames using direct-displacement-based and forcebased approaches. Innov Infrastruct Solut 5(3):115. https://doi. org/10.1007/s41062-020-00364-1

24. Wijesundara K, Rajeev P (2012) Direct displacement-based seismic design of steel concentric braced frame structures. Aust J Struct Eng 13(3):243-258. https://doi.org/10.7158/S11-135. 2012.13.3

25. Al-Mashaykhi M, Rajeev P, Wijesundara KK, Hashemi MJ (2019) Displacement profile for displacement based seismic design of concentric braced frames. J Constr Steel Res 155:233248. https://doi.org/10.1016/j.jcsr.2018.12.029

26. Sahoo DR, Prakash A (2019) Seismic behavior of concentrically braced frames designed using direct displacement-based method. Int J Steel Struct 19(1):96-109. https://doi.org/10. 1007/s13296-018-0092-0

27. Rahman MA, Sritharan S (2006) An evaluation of force-based design vs. direct displacement-based design of jointed precast post-tensioned wall systems. Earthq Eng Eng Vib 5(2):285-296. https://doi.org/10.1007/s11803-006-0620-3

28. Sullivan TJ, Priestley MJN, Calvi GM (2006) Direct displacement-based design of frame-wall structures. J Earthquake Eng 10:91-124. https://doi.org/10.1080/13632460609350630

29. Qureshi IM, Warnitchai P (2016) Computer modeling of dynamic behavior of rocking wall structures including the impact-related effects. Adv Struct Eng 19(8):1245-1261. https://doi.org/10.1177/ 1369433216642057

30. Aragaw LF, Calvi PM (2020) Comparing the performance of traditional shear-wall and rocking shear-wall structures designed using the direct-displacement based design approach. Bull Earthq Eng 18(4):1345-1369. https://doi.org/10.1007/s10518-019-00740-y

31. Sullivan TJ, Lago A (2012) Towards a simplified Direct DBD procedure for the seismic design of moment resisting frames with viscous dampers. Eng Struct 35:140-148. https://doi.org/ 10.1016/j.engstruct.2011.11.010

32. Chaudhury D, Singh Y (2014) Performance-based design of RC frame buildings with metallic and friction dampers. J Inst Eng India Ser A 95:239-247. https://doi.org/10.1007/ s40030-014-0089-4

33. Karmakar S, Kumar S, Dutta SC, Hussain A (2018) Base isolation versus dual design philosophy for seismic design of buildings: preliminary case study. J Inst Eng India Ser A 99:627-635. https://doi.org/10.1007/s40030-018-0320-9

34. Priestley MJN, Calvi GM, Kowalsky MJ (2007) Displacementbased seismic design of structures. IUSS Press, Pavia

35. IS 456 (2000) Indian standard plain and reinforced concrete, code of practice. Bureau of Indian Standards, New Delhi

36. IS 875 (2015) Indian standard code of practice for design loads (other than earthquake) for buildings and structures,part-1, dead loads. Bureau of Indian standards, New Delhi

37. IS 875 (2015) Indian standard code of practice for design loads (other than earthquake) for buildings and structures,part-2, imposed loads. Bureau of Indian standards, New Delhi

38. Sharma AK, Tripathi R, Bhat G (2020) Comparative performance evaluation of RC frame structures using direct displacement-based design method and force-based design method. Asian J Civ Eng 21(3):381-394. https://doi.org/10.1007/s42107-019-00198-y

39. FEMA 356 (2000) Prestandard and commentary for the seismic rehabilitation of buildings. Federal Emergency Management Agency, Washington, D.C 
40. Kwon OS, Elnashai A (2006) The effect of material and ground motion uncertainty on the seismic vulnerability curves of RC structure. Eng Struct 28(2):289-303. https://doi.org/10.1016/j. engstruct.2005.07.010

41. Sil A, Sherpa DZ, Hait P (2019) Assessment on combined effects of multiple engineering demand parameters (MEDP) contributing on the shape of fragility curve. J Build Pathol Rehabil 4 (1). https://doi.org/10.1007/s41024-019-0047-7

42. FEMA P695 (2009) Quantification of building seismic performance factors. Federal Emergency Management Agency, Washington D.C

43. Reyes JC, Kalkan E (2012) How many records should be used in an ASCE/SEI-7 ground motion scaling procedure? Earthq Spectra 28(3):1223-1242. https://doi.org/10.1193/1.4000066

44. Center for Engineering Strong Motion Data. URL: https ://stron gmotioncenter.org/

45. SeismoMatch (2020) A computer program for an application capable of adjusting earthquake records. http://www.seismosoft.com/ seismomatch/. Accessed 18 Jan 2021

46. CSI and SAP2000 (2020) Integrated software for structural analysis and design. Computer and Structures Inc., Berkeley
47. Malekpour S, Dashti F (2013) Application of the direct displacement based design methodology for different types of RC structural systems. Int J Concrete Struct Mater 7(2):135-153. https:// doi.org/10.1007/s40069-013-0043-2

48. Muljati I, Kusuma A, Hindarto F (2015) Direct displacement based design on moment resisting frame with out-of-plane offset of frame. Procedia Engineering 125:1057-1064. https://doi.org/ 10.1016/j.proeng.2015.11.162

49. Varughese JA, Menon D, Meher Prasad A (2014) Load distribution patterns for displacement-based seismic design of RC framed buildings. J Inst Eng India Ser A 95:211-219. https://doi.org/10. 1007/s40030-014-0094-7

50. Abebe BH, Lee JS (2019) Accounting for torsional response in direct displacement-based design of plan-asymmetric reinforced concrete frame buildings. KSCE J Civ Eng 23(3):1190-1206. https://doi.org/10.1007/s12205-019-1739-x

51. Yan L, Gong J (2019) Development of displacement profiles for direct displacement based seismic design of regular reinforced concrete frame structures. Eng Struct 190:223-237. https://doi. org/10.1016/j.engstruct.2019.04.015 